\title{
Development of a Digestion Method for the Determination of Inorganic Contaminants in Polyvinyl Acetate (PVAc)
}

\author{
Erika Matoso and Solange Cadore*
}

Departamento de Química Analítica, Instituto de Química, CP 6154, 13084-971 Campinas-SP, Brazil

\begin{abstract}
Neste trabalho estão descritos alguns métodos para a digestão de amostras de emulsão aquosa de acetato de polivinila visando à determinação de $\mathrm{As}, \mathrm{B}, \mathrm{Cd}, \mathrm{Cr}, \mathrm{Cu}, \mathrm{Fe}, \mathrm{Hg}, \mathrm{Ni}, \mathrm{Pb}$ e $\mathrm{Sb}$ por espectrometria de emissão óptica em plasma com acoplamento indutivo (ICP OES). Foram estudados métodos clássicos como calcinação, digestão ácida (a baixa temperatura e a alta temperatura) em chapa de aquecimento e também a digestão assistida por microondas (MW). Nas condições otimizadas (MW) obteve-se apenas $0,1 \%$ de conteúdo de carbono residual (RCC), recuperações das espécies estudadas entre 100 e $107 \%$, com RSD entre 0,5 e 2,5\% e limites de quantificação entre 0,003 e $0,29 \mathrm{mg} \mathrm{kg}^{-1}$
\end{abstract}

Digestion method for the determination of $\mathrm{As}, \mathrm{B}, \mathrm{Cd}, \mathrm{Cr}, \mathrm{Cu}, \mathrm{Fe}, \mathrm{Hg}, \mathrm{Ni}, \mathrm{Pb}$ and $\mathrm{Sb}$ by inductively coupled plasma optical emission spectrometry (ICP OES) in samples of polyvinyl acetate water emulsions were developed. A comparison between classical methods like calcination, acid digestion (low temperature and high temperature) on a heating plate and microwave digestion (MW) was made. Under optimum conditions, using the MW procedure, only $0.1 \%$ of residual carbon content (RCC) was found as residue and recoveries between 100 and $107 \%$, with RSD between 0.5 and $2.5 \%$ and quantification limits between 0.003 and $0.29 \mathrm{mg} \mathrm{kg}^{-1}$ were obtained.

Keywords: inorganic constituents, polyvinyl acetate, microwave digestion, ICP OES

\section{Introduction}

Polymers are macromolecules formed from small molecules, the monomers, through a polymerization reaction. They are classified according to the synthesis process. As with many vinyl polymers, polyvinyl acetate (PVAc) is produced by the polymerization of vinyl acetate in the presence of a catalyst (usually hydrogen peroxide or an organic peroxide). It is a transparent material easily dissolved in many organic solvents and shows molar mass in the range between 3500 and 50,000. ${ }^{1}$

Polymers have become an increasingly important group in the general field of engineering materials. Their range of properties and applications is as important as that of other major classes of materials and, associated with the ease of fabrication, make it possible to produce finished items with low cost. Some important industries such as those of fibers, rubbers, plastics, adhesives and sealants are based on polymers. ${ }^{2}$

*e-mail: cadore@iqm.unicamp.br
Some papers have described the development of analytical methods for metal determination in polymers samples, ${ }^{3-6}$ most of them involving determination of lead, cadmium, chromium and mercury in packaging material. In case these materials are used for food products the migration of heavy metals to the food is of great concern. Chromium, particularly when it occurs as $\mathrm{Cr}$ (VI), is known as a human carcinogen and mutagen.

According to the EU 94/62/EC directive defines the maximum limits of total heavy metals $(\mathrm{Hg}, \mathrm{Cd}, \mathrm{Pb}, \mathrm{Cr})$ that may be present in packaging materials as $100 \mathrm{mg} \mathrm{kg}^{-1}$.

There are not many papers from the last decade that deal with this subject ${ }^{8}$ and additionally there are also only a few certified materials that may be used to validate analytical methodologies, but this field is growing. The most analyzed samples are solid polymers such as polyethylene, polystyrene and polyvinyl chloride, but there are few methodologies for emulsion polymers like polyvinyl acetate (PVAc).

Polyvinyl acetate finds numerous applications in the manufacture of emulsion paints, varnishes and adhesives. ${ }^{2}$ 
In many countries it has been used as a masticatory substance in chewing gum base. ${ }^{9}$ It is also used in cosmetics as a binder, emulsion stabilizer, and hair fixative. ${ }^{10}$

The aim of this work is to develop a sample treatment procedure for polyvinyl acetate in order to determine possible contaminant elements, such as $\mathrm{As}, \mathrm{B}, \mathrm{Cd}, \mathrm{Cr}, \mathrm{Cu}$, $\mathrm{Fe}, \mathrm{Hg}, \mathrm{Ni}, \mathrm{Pb}$ and $\mathrm{Sb}$, by ICP OES.

\section{Experimental}

\section{Instrumentation}

All the measurements were made with a Varian Vista MPX (axial view) inductively coupled plasma optical emission spectrometer (ICP OES), equipped with a solidstate charge-coupled device detector (CCD), a peristaltic pump and a "Seaspray" nebulizer coupled to a cyclonic nebulization chamber. A CCI (Cooled Cone Interface) interface was set with an argon flow rate of $3 \mathrm{~L} \mathrm{~min}^{-1}$. The conditions of operation of the spectrometer are presented in Table 1.

For sample treatment a microwave oven (Milestone ETHOS TC), an oven and a hot plate were used, depending on the experiment. In order to measure the residual carbon content all the samples were analyzed before the ICP OES measurements using a Shimadzu TOC-V CPN.

The thermo gravimetric analysis (TGA) of samples was carried out with a Mettler Toledo TC 15 equipment.

The determination of the elemental chemical composition of the samples studied was made by means of scanning electron microscopy (SEM) associated to electron dispersive spectroscopy (EDS), using a JSM6340F scanning electron microscope (JEOL Ltd.).

\section{Solutions and reagents}

Pure argon (99.996 \%, White Martins, SP, Brazil) was used. Analytical solutions $1000 \mathrm{mg} \mathrm{L}^{-1}$ in $2 \% \mathrm{v} / \mathrm{v} \mathrm{HNO}_{3}$ (Carlo Erba Analyticals) of each analyte were used. All the glassware used was cleaned with dilute nitric acid $(10 \% \mathrm{v} / \mathrm{v})$ and then with deionized water (MilliQ system, $18.2 \mathrm{M} \Omega \mathrm{cm})$.

The $70 \%(\mathrm{~m} / \mathrm{m})$ nitric, $37 \%(\mathrm{~m} / \mathrm{m})$ hydrochloric and $98 \%(\mathrm{~m} / \mathrm{m})$ sulfuric acid, as well as the $30 \%(\mathrm{~m} / \mathrm{m})$ hydrogen peroxide were from Merck. The stock ICP solutions (1000 $\left.\mathrm{mg} \mathrm{L}^{-1}\right)$ were Chemis or TecLab with certified concentrations. All working standards were matrix matched and prepared in class A volumetric flasks. All other reagents were at least p.a. grade.

The samples used in this work were non-ionic water emulsions of polyvinyl acetate with additives and polyvinyl

Table 1. Instrument operating conditions for the determination of metals in polyvinyl acetate

Radio frequency power/(kW)
Plasma gas flow rate/(L $\left.\mathrm{min}^{-1}\right)$
Auxiliary argon flow rate/(L min
Nebulizer pressure/(kPa)
Replicate read time/(s)
Pump rate/(rpm)
Replicates
Wavelengths/(nm)

Sample uptake delay/(s)

Pump rate/(rpm)

Rinse time/(s)

Replicates

(*) This instrument is not fitted with a mass flow controller, this way setting nebulizer is by pressure. A pressure of $200 \mathrm{kPa}$ is about $0.69 \mathrm{~mL} \mathrm{~min}^{-1}$.

$(* *)$ The sample uptake rate is set adjusting the peristaltic pump speed.

alcohol. pH was set between 4-5, the viscosity 16,000 and $22,000 \mathrm{mPa} \mathrm{s}$, at $25^{\circ} \mathrm{C}$, and the solid content was 51 to $53 \%$.

\section{Procedure}

The sample was treated by different procedures in order to determine the best treatment. In this way, calcination, acid digestions at low and high temperature and digestion by microwave radiation were studied. Considering the lack of standard reference material, the samples were enriched with the analytes of interest and submitted to the treatment. The resulting material was then diluted appropriately before analysing by ICP OES.

\section{Sample treatment}

For all the investigated procedures, samples were taken in terms of mass, which depends on the treatment: 0.1-0.5 g for microwave digestion; $1-1.5 \mathrm{~g}$ for acid digestion and $10 \mathrm{~g}$ for calcinations procedure.

In order to verify the accuracy of the digestion treatments the sample was spiked with $0.10 \mathrm{mg}$ of the analytes by using a $100 \mathrm{mg} \mathrm{kg} \mathrm{kg}^{-1}$ solution and recovery values were evaluated.

\section{Calcination}

The sample was dried in an oven $\left(105 \pm 5^{\circ} \mathrm{C}\right)$ for $2 \mathrm{~h}$ and then was analyzed by TGA to obtain the minimum temperature where all organic material was decomposed. After the calcination temperature has been set, about $10 \mathrm{~g}$ of 
samples were weighed in a platinum crucible and $0.10 \mathrm{mg}$ of each element to be analyzed was added. It was dried for $2 \mathrm{~h}\left(105 \pm 5^{\circ} \mathrm{C}\right)$ and burned in a conventional oven, with refractory material and without air circulation. Calcination was carried out using 4 crucibles at a time, because of the oven size. After reaching the room temperature, it was added $5 \mathrm{~mL}$ of $37 \%$ hydrochloric acid and samples were heated at $100{ }^{\circ} \mathrm{C}$ on a hot plate, for $60 \mathrm{~min}$.

\section{Acid digestion (low temperature)}

About $1 \mathrm{~g}$ of sample was weighed into a $250 \mathrm{~mL}$ beaker and $0.10 \mathrm{mg}$ of each element under analyses was added. The digestion was carried out on a hot plate $\left(60-70{ }^{\circ} \mathrm{C}\right)$ using an oxidant mixture: $98 \% \mathrm{~m} / \mathrm{m} \mathrm{H}_{2} \mathrm{SO}_{4}(5 \mathrm{~mL})$ and $70 \%$ $\mathrm{m} / \mathrm{m} \mathrm{HNO}_{3}(2.5 \mathrm{~mL})$ plus $7.5 \% \mathrm{~m} / \mathrm{v} \mathrm{KMnO}_{4}(10 \mathrm{~mL})$. After $15 \mathrm{~min}, 5 \mathrm{~mL}$ of $8 \% \mathrm{~m} / \mathrm{v}$ potassium persulphate solution was added and the mixture was rested for $24 \mathrm{~h}$ leading to a sample partial digestion. The carbonized residue was separated by filtration.

\section{Acid digestion (high temperature)}

About $1.5 \mathrm{~g}$ of the sample and $0.10 \mathrm{mg}$ of each element to be analyzed were transferred into a $250 \mathrm{~mL}$ beaker. The digestion was carried out in a hot plate $\left(250{ }^{\circ} \mathrm{C}\right)$ using $10 \mathrm{~mL}$ of $98 \% \mathrm{~m} / \mathrm{m}$ sulfuric acid and additional aliquots of $5 \mathrm{~mL}$ were added until obtain a black liquid, that indicate complete sample carbonization. Aliquots of $10 \mathrm{~mL}$ of $30 \% \mathrm{~m} / \mathrm{m}$ hydrogen peroxide were then added until a pale yellow solution was obtained.

\section{Microwave digestion (closed vessel)}

About $0.5 \mathrm{~g}$ sample was weighed into a High Pressure TFM vessel (maximum pressure of 100 bar and maximum temperature of $260{ }^{\circ} \mathrm{C}$ ), together with $5 \mathrm{~mL}$ of concentrated $\mathrm{HNO}_{3}$ and $3 \mathrm{~mL} \mathrm{H}_{2} \mathrm{O}$ as well as $0.1 \mathrm{mg}$ of each element to be analyzed (this addition was made from a $100 \mathrm{mg} \mathrm{kg}^{-1}$ solution), and the sample was underwent the following treatment: $7 \mathrm{~min}$ at $120{ }^{\circ} \mathrm{C}(400 \mathrm{~W}) ; 5 \mathrm{~min}$ at $120{ }^{\circ} \mathrm{C}$ $(400 \mathrm{~W}) ; 5 \mathrm{~min}$ at $180{ }^{\circ} \mathrm{C}(400 \mathrm{~W}) ; 20 \mathrm{~min}$ at $180{ }^{\circ} \mathrm{C}$ $(400 \mathrm{~W})$. After cooling, the solution was diluted to $50 \mathrm{~mL}$ with water and the emission intensity was measured against an analytical curve.

\section{Analysis of glue samples}

Three samples of glue (PVAc base), identified by SC, BI, $\mathrm{GR}$, were analyzed with the following procedure. Aliquots of $0.5 \mathrm{~g}$ of sample were weighed, then $5 \mathrm{~mL}$ of conc. $\mathrm{HNO}_{3}$ and $3 \mathrm{~mL}$ of $\mathrm{H}_{2} \mathrm{O}$ were added (for recovery test, $0.1 \mathrm{mg}$ of each element was added) to the High Pressure TFM vessels and submitted to the following treatment: $7 \mathrm{~min}$ at $120^{\circ} \mathrm{C}$ $(400 \mathrm{~W}) ; 5 \mathrm{~min}$ at $120^{\circ} \mathrm{C}(400 \mathrm{~W}) ; 5 \mathrm{~min}$ at $180^{\circ} \mathrm{C}(800 \mathrm{~W})$; $20 \mathrm{~min}$ at $180^{\circ} \mathrm{C}(800 \mathrm{~W})$. After cooling, the solution was diluted to $50 \mathrm{~mL}$ with water and the emission intensity was measured against an analytical curve.

\section{Results and Discussion}

Sample analysis by TGA shows that resin decomposition occurs about $340{ }^{\circ} \mathrm{C}$ and there are another decomposition peaks at 440 and $550{ }^{\circ} \mathrm{C}$ that can be resulted from organic additives used in the PVAc formulation (Figure 1).

MEV-EDS analysis shows that after calcinations at $600{ }^{\circ} \mathrm{C}$ the major components of polyvinyl acetate are $\mathrm{Na}$, $\mathrm{O}$ and $\mathrm{S}$ and among the minor components are $\mathrm{C}, \mathrm{Al}, \mathrm{Si}$ and $\mathrm{K}$. This result suggests the presence of sodium sulfate, silica or aluminum silicate and alkali sodium carbonates.

\section{Calcination}

The result of TGA analysis shows that a temperature of $600{ }^{\circ} \mathrm{C}$ is adequate for calcination. However, it is possible to conclude that this procedure is not recommended for this work because several elements are lost. The results obtained for different elements are shown in Table 2. Recoveries of about $60 \%$ were obtained for most the elements but in the case of mercury and cadmium, the values are not higher than $10 \%$ due to their volatility.

\section{Acid digestion (low temperature and high temperature)}

The analysis by ICP OES of the samples treated by acid digestion on a hot plate shows a significant enhancement in recovery values. The use of more drastic conditions, such as sulfuric acid and high temperature $\left(250^{\circ} \mathrm{C}\right)$ leads to better results but still not quantitative, as shown in Table 3 . The use of a higher temperature was especially inconvenient for $\mathrm{Cd}, \mathrm{Pb}$ and $\mathrm{Hg}$.

\section{Microwave digestion}

In order to overcome the previous problems and to obtain quantitative recoveries for all the elements a procedure using microwave radiation was investigated.

Some reagents such as nitric acid, hydrogen peroxide, sulfuric acid and perchloric acid are strong oxidizing agents generally used for digestion of organic samples. Nitric acid is preferred due to its compatibility with instrumental methods, safety and ease of purification. ${ }^{4}$ There are some 


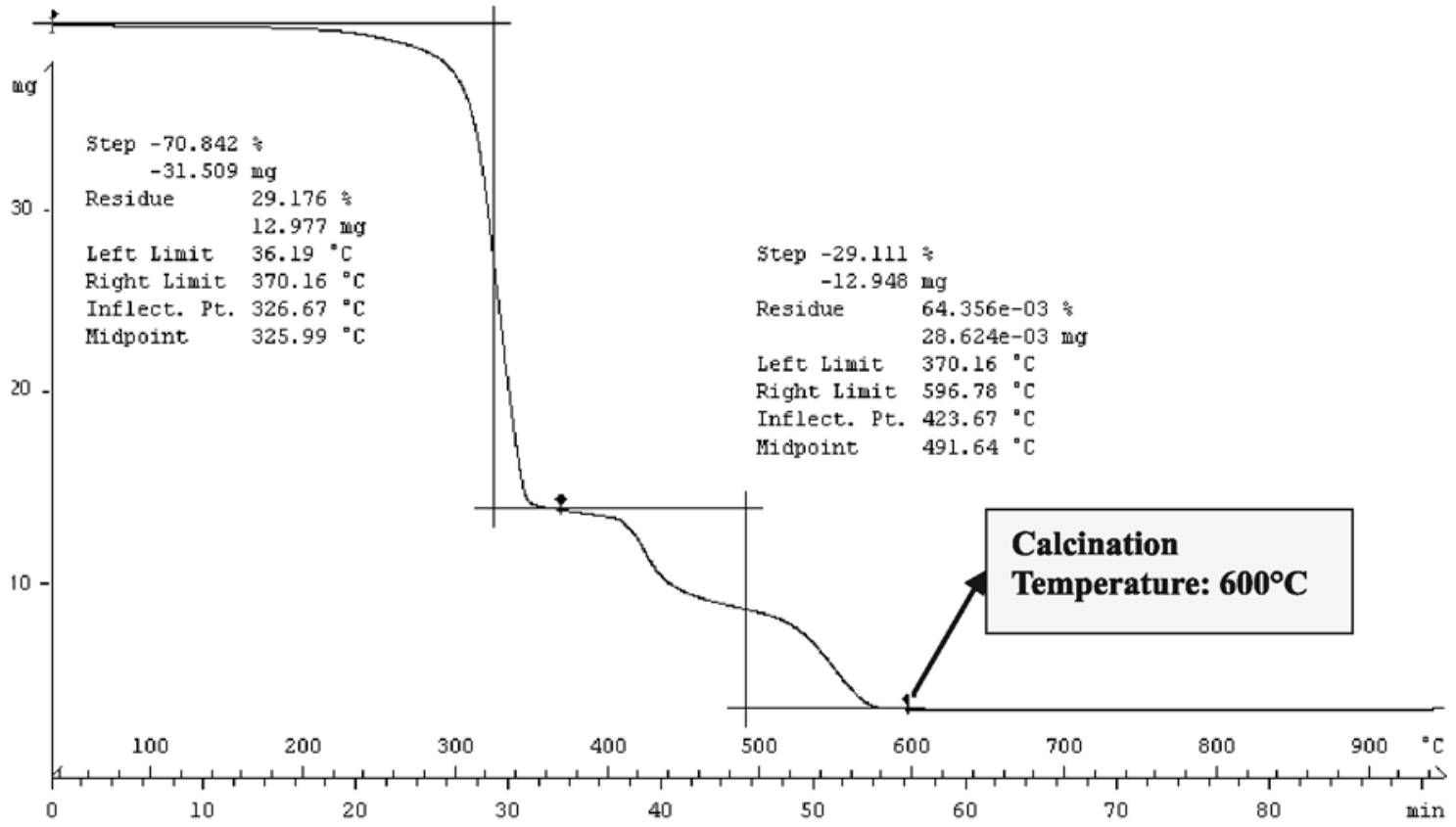

Figure 1. TG curve (thermogravimetric) of PVAc (dry residue).

authors who use microwave digestion for polymers materials ${ }^{3-6,8}$ such as polystyrene, polyethylene, polyvinyl chloride and polypropylene, but considering the lack of data

Table 2. Element contents obtained after sample treatment by calcinations $(n=3)$

\begin{tabular}{ccccc}
\hline Metal & $\begin{array}{c}\text { Concentration } \\
\text { added/(mg L }\end{array}$ & $\begin{array}{c}\text { Recovery } \\
\text { concentration / } \\
\left(\mathrm{mg} \mathrm{L}^{-1}\right)\end{array}$ & $\begin{array}{c}\text { Standard } \\
\text { Deviation/ } \\
\left(\mathrm{mg} \mathrm{L}^{-1}\right)\end{array}$ & Recovery/(\%) \\
\hline $\mathrm{As}$ & 1.94 & 1.30 & 0.11 & 67 \\
$\mathrm{~B}$ & 2.05 & 1.67 & 0.16 & 82 \\
$\mathrm{Cd}$ & 1.99 & 0.21 & 0.05 & 10 \\
$\mathrm{Cr}$ & 1.98 & 0.47 & 0.16 & 24 \\
$\mathrm{Cu}$ & 2.00 & 1.18 & 0.05 & 59 \\
$\mathrm{Fe}$ & 2.00 & 1.15 & 0.27 & 57 \\
$\mathrm{Hg}$ & 2.01 & 0.04 & 0.01 & 1.9 \\
$\mathrm{Ni}$ & 1.98 & 0.84 & 0.17 & 43 \\
$\mathrm{~Pb}$ & 1.99 & 1.19 & 0.06 & 60 \\
$\mathrm{Sb}$ & 2.06 & 0.73 & 0.12 & 35 \\
\hline
\end{tabular}

for polymers emulsions, optimizations tests were carried out in this work.

The parameters optimized were: (i) sample weight (0.1-0.5 g); (ii) nitric acid volume (10-5 mL) and (iii) water volume $(0-4 \mathrm{~mL})$, in order to achieve greater sample weight, better LOD and lower acidity content. During this optimization a pressure sensor was used and the limit pressure was set as 30 bar. The minimum volume for the experiment was $8 \mathrm{~mL}$ because this is the lowest volume that sensor temperature needs for work well. After optimization experiments, the following reagents composition was chosen as optimum: (i) $0.5 \mathrm{~g}$; (ii) $5 \mathrm{~mL}$ and (iii) $3 \mathrm{~mL}$, respectively.

After the digestion of samples at optimum conditions, RCC analysis was carried out. The presence of organic compounds may lead to a low performance of ICP OES spectrometer due to the emission of carbon and

Table 3. Element contents obtained after sample treatment by acid digestion (low and high temperature), $(n=3)$

\begin{tabular}{|c|c|c|c|c|c|c|c|c|}
\hline Metal & $\begin{array}{c}\text { Conc. added } \\
\text { Low } \mathrm{T} /\left(\mathrm{mg} \mathrm{L}^{-1}\right)\end{array}$ & Mean/(mg L $\left.{ }^{-1}\right)$ & $\begin{array}{c}\text { Standard } \\
\text { Deviation } /\left(\mathrm{mg} \mathrm{L}^{-1}\right)\end{array}$ & Recovery/(\%) & $\begin{array}{c}\text { Conc. added } \\
\text { High } \mathrm{T} /\left(\mathrm{mg} \mathrm{L}^{-1}\right)\end{array}$ & Mean/(mg L $\left.{ }^{-1}\right)$ & $\begin{array}{c}\text { Standard } \\
\text { Deviation } /\left(\mathrm{mg} \mathrm{L}^{-1}\right)\end{array}$ & Recovery/(\%) \\
\hline$\overline{\text { As }}$ & 1.95 & 1.59 & 0.10 & 81 & 1.59 & 1.71 & 0.20 & 88 \\
\hline B & 1.87 & 1.57 & 0.13 & 84 & 1.99 & 1.71 & 0.49 & 86 \\
\hline $\mathrm{Cd}$ & 2.13 & 1.11 & 0.06 & 52 & 2.06 & 1.39 & 0.22 & 68 \\
\hline $\mathrm{Cr}$ & 2.19 & 1.66 & 0.09 & 76 & 2.01 & 1.48 & 0.17 & 74 \\
\hline $\mathrm{Cu}$ & 2.19 & 1.23 & 0.09 & 56 & 2.09 & 1.49 & 0.13 & 71 \\
\hline $\mathrm{Fe}$ & 2.22 & 1.43 & 0.08 & 64 & 2.06 & 2.10 & 0.15 & 102 \\
\hline $\mathrm{Hg}$ & 1.83 & 1.29 & 0.07 & 71 & 1.95 & 0.31 & 0.07 & 16 \\
\hline $\mathrm{Ni}$ & 2.18 & 1.29 & 0.16 & 59 & 2.04 & 1.39 & 0.20 & 68 \\
\hline $\mathrm{Pb}$ & 2.13 & 1.27 & 0.07 & 60 & 2.03 & 0.41 & 0.40 & 20 \\
\hline $\mathrm{Sb}$ & 1.70 & 1.33 & 0.08 & 78 & 1.93 & 1.47 & 0.16 & 76 \\
\hline
\end{tabular}


its compounds that increase the background signal. The proposed treatment leads to values lower than $0.1 \%$ of residual carbon in the digested solution. The analytical results described in Table 4 show that this procedure is ideal for this kind of sample. Quantitative recoveries for all the elements were obtained.

Comparing all the sample treatment studied in this work, it is possible to conclude that calcination is the simplest one, but its recoveries are also the lowest. Acid digestion procedures showed acceptable results for some elements (75-125\%), ${ }^{11}$ but for simultaneous determination they cannot be used, because some elements like $\mathrm{Hg}$, As and $\mathrm{Pb}$ are lost when the sample is burned. Another problem is concerning the release of acetic acid when PVAc is heated with acid or burned. ${ }^{1}$ In this case, some metal acetates decompose when burned and can be lost.

The acid digestion at low temperature procedure is currently used for the determination of $\mathrm{Hg}^{12}$ in sediments and fish tissue. When applied to PVAc the recovery obtained $(71 \%)$ was better than that found at high temperature digestion $(16 \%)$, but the residual carbon content was higher, and also the analysis time $(24 \mathrm{~h})$. Otherwise, the recovery for some elements like $\mathrm{Cd}, \mathrm{Cu}, \mathrm{Fe}, \mathrm{Ni}$ and $\mathrm{Pb}$ was not acceptable.

In conclusion, the best results were obtained using microwave digestion that provides recoveries between 100 and $107 \%$, for all the elements studied in PVAc sample. In this way, this procedure was adopted for glue samples.

Table 4. Element contents obtained after sample treatment by microwave digestion (closed vessel) in the polyvinyl acetate analysis by ICP OES, $(n=3)$

\begin{tabular}{lcccc}
\hline Metal & $\begin{array}{c}\text { Concentration } \\
\text { added/(mg L }\end{array}$ & $\begin{array}{c}\text { Concentration } \\
\text { found/(mg L }\end{array}$ & $\begin{array}{c}\text { Standard } \\
\text { Deviation/ } \\
\left(\mathrm{mg} \mathrm{L}^{-1}\right)\end{array}$ & $\begin{array}{c}\text { Recovery/ } \\
(\%)\end{array}$ \\
\hline $\mathrm{As}$ & 2.03 & 2.17 & 0.05 & 107 \\
$\mathrm{~B}$ & 2.04 & 2.09 & 0.01 & 103 \\
$\mathrm{Cd}$ & 2.02 & 2.10 & 0.02 & 104 \\
$\mathrm{Cr}$ & 2.04 & 2.10 & 0.03 & 103 \\
$\mathrm{Cu}$ & 2.07 & 2.06 & 0.02 & 100 \\
$\mathrm{Fe}$ & 2.05 & 2.11 & 0.02 & 103 \\
$\mathrm{Hg}$ & 2.01 & 2.16 & 0.04 & 107 \\
$\mathrm{Ni}$ & 2.03 & 2.08 & 0.02 & 102 \\
$\mathrm{~Pb}$ & 2.02 & 2.05 & 0.01 & 101 \\
$\mathrm{Sb}$ & 2.03 & 2.15 & 0.02 & 106 \\
\hline
\end{tabular}

RSD in the range of $0.5-2.5 \%$.

\section{Analysis of glue samples}

The analysis of the glue samples without analyte addition (Table 5) showed that the concentrations of the analytes are lower than the limit of quantification (LOQ), except for iron. It is important to point that LOQ was
Table 5. Element contents obtained after sample treatment by microwave digestion (closed vessel) in the Glue samples by ICP OES

\begin{tabular}{lccccc}
\hline Metal & SC & BI & GR & LOQ & LOQ $\times$ DF \\
\hline $\mathrm{As}$ & $<$ LOQ & $<$ LOQ & $<$ LOQ & 0.15 & 15.1 \\
$\mathrm{~B}$ & $<$ LOQ & $<$ LOQ & $<$ LOQ & 0.09 & 8.5 \\
$\mathrm{Cd}$ & $<$ LOQ & $<$ LOQ & $<$ LOQ & 0.01 & 0.7 \\
$\mathrm{Cr}$ & $<$ LOQ & $<$ LOQ & $<$ LOQ & 0.003 & 0.3 \\
$\mathrm{Cu}$ & $<$ LOQ & $<$ LOQ & $<$ LOQ & 0.07 & 7.2 \\
$\mathrm{Fe}$ & 4.1 & 6.9 & $<$ LOQ & 0.02 & 1.5 \\
$\mathrm{Hg}$ & $<$ LOQ & $<$ LOQ & $<$ LOQ & 0.04 & 3.8 \\
$\mathrm{Ni}$ & $<$ LOQ & $<$ LOQ & $<$ LOQ & 0.01 & 1.1 \\
$\mathrm{~Pb}$ & $<$ LOQ & $<$ LOQ & $<$ LOQ & 0.05 & 5.0 \\
$\mathrm{Sb}$ & $<$ LOQ & $<$ LOQ & $<$ LOQ & 0.29 & 29.4 \\
\hline
\end{tabular}

Table 6. Element contents obtained after recovery addition of elements in Glue samples treatment by microwave digestion (closed vessel) by ICP OES

\begin{tabular}{lccc}
\hline Metal & $\begin{array}{c}\text { Recovery (\%) } \\
\text { Sample GR }\end{array}$ & $\begin{array}{c}\text { Recovery (\%) } \\
\text { Sample SC }\end{array}$ & $\begin{array}{c}\text { Recovery (\%) } \\
\text { Sample BI }\end{array}$ \\
\hline $\mathrm{As}$ & 99.3 & 95.3 & 94.2 \\
$\mathrm{~B}$ & 100.0 & 93.8 & 94.1 \\
$\mathrm{Cd}$ & 96.0 & 88.2 & 89.2 \\
$\mathrm{Cr}$ & 100.0 & 93.2 & 95.4 \\
$\mathrm{Cu}$ & 98.3 & 89.7 & 94.3 \\
$\mathrm{Fe}$ & 100.5 & 98.5 & 93.3 \\
$\mathrm{Hg}$ & 93.4 & 103.2 & 101.9 \\
$\mathrm{Ni}$ & 96.1 & 88.1 & 90.8 \\
$\mathrm{~Pb}$ & 95.2 & 87.1 & 90.6 \\
$\mathrm{Sb}$ & 97.0 & 90.1 & 87.5 \\
\hline
\end{tabular}

multiplied by dilution factor (100 times). Thus, it was carried out an addition and recovery experiment for these samples and the results are presented in Table 6.

\section{Figures of merits}

Analytical curves from all the elements were constructed in $5 \% \mathrm{~m} / \mathrm{v}$ nitric acid and the correlation coefficients were evaluated.

The precision of the method was evaluated by analyzing 10 sample replicates and relative standard deviations less than $5 \%$ were obtained for different concentrations of all the elements.

Regarding the data obtained from analytical curves, the limit of quantification $(10 \sigma)$ calculated for the studied elements are $\left(\mathrm{ng} \mathrm{L}^{-1}\right): 151 ; 85 ; 7 ; 3 ; 72 ; 15 ; 38 ; 11,50$ and 294 for $\mathrm{As}, \mathrm{B}, \mathrm{Cd}, \mathrm{Cr}, \mathrm{Cu}, \mathrm{Fe}, \mathrm{Hg}, \mathrm{Ni}, \mathrm{Pb}$ and $\mathrm{Sb}$, respectively.

\section{Conclusions}

The best results for the determination of metals in polyvinyl acetate were achieved using microwave digestion. The 
proposed method makes possible to determine all the metals (As, B, Cd, Cr, Cu, Fe, Hg, Ni, Pb and $\mathrm{Sb}$ ) simultaneously with good repeatability (RSD between 0.5 and $2.5 \%$ ) and recoveries values of 100 to $107 \%$ for base product (PVAc) and between 87 and $103 \%$ for the glue samples.

The LOQ $\times$ DF were below the values recommended for regulatory agencies data ${ }^{13}$ for toxic elements in glue samples, for the elements studied in this work. For further developments another elements ( $\mathrm{Ba}$ and $\mathrm{Se}$ ) will be studied.

\section{Acknowledgments}

The authors gratefully acknowledge Dr. Carol H. Collins for assistance with English in this manuscript, and the Conselho Nacional de Desenvolvimento Científico e Tecnológico (CNPq) for financial support of this work.

\section{References}

1. Urbanski, J.; Czerwinski, W.; Janicka, K.; Majewska, F.; Zowall, H.; Handbook of Analysis of Synthetic Polymers and Plastics, Ellis Horwood: England, 1977, p. 388.

2. Feldman, D.; Polymeric Building Materials, Elsevier Applied Science: London and New York, 1989, p.1
3. Perring, L.; Alonso, M. I.; Andrey, D.; Bourqui, B.; Zbinden, P.; Fresenius J. Anal. Chem. 2001, 370, 76.

4. Eilola, K.; Peramaki, P.; Analyst 2003, 128, 194.

5. Sakurai, H.; Noro, J.; Kawase, A.; Fujinami, M.; Oguyma, K.; Anal. Sci. 2006, 22, 225.

6. Besecker, K. D.; Rhoades, C. B.; Jones, B. T.; Barnes, K. W.; At. Spectrosc. 1998, 19, 55.

7. Skrzydlewska, E.; Balcerzak, M.; Vanhaecke, F.; Anal. Chim. Acta 2003, 479, 191.

8. Cadore, S.; Matoso, E.; Santos, M. C.; Quim. Nova 2008, 31, 1533.

9. Sugita, T.; Kamasaki, Y.; Nagata, M.; Ishiwata, H.; Yamada, T.; J. Food Hygen. Soc. Jap. 1998, 39, 410.

10. Andersen, F. A.; J. Am. College Toxicol. 1996, 15, 166.

11. Varian ICP Expert II Help, Instrument Optimization, Spikes, 2005.

12. Brown, H.G.; Hensley, C. P.; Thale, J.E.; Trans. Kansas Acad. Sci. 1973, 76, 4 (www.jstor.org).

13. ABNT, Associação Brasileira de Normas Técnicas; "NBRNM300-3 of 2007/09/30, Safety of toys, Part 3: Migration of certain elements, São Paulo, Brazil, 2007.

Received: October 20, 2007 Web Release Date: August 6, 2008

FAPESP helped in meeting the publication costs of this article. 